\title{
RELATIONSHIP BETWEEN PRINCIPALS' LEADERSHIP STYLES AND TEACHERS' PROFESSIONAL COMMITMENT IN PUBLIC SCHOOLS OF ZIARAT, BALOCHISTAN
}

\author{
Zarmina Panezai \\ University of Management \& Technology (UMT) \\ zerminapanezai@gmail.com \\ Madiha Shah \\ University of Management \& Technology (UMT) \\ madihashah.phd@gmail.com
}

\begin{abstract}
The leadership of school principal plays a vital role in the success of an institution (Vernon-Dotson, 2008) as well as in the betterment of student outcomes (DuFour \& Mattos, 2013). However, this success is not possible unless the teachers are committed to their profession (Altun, 2017). The present study examines the insight of teachers concerning the leadership approaches of their school principals, and its association with the teachers' professional commitment. Data were gathered from 243 teachers working in 33 (19 boys and 14 girls) public schools across District Ziarat, Balochistan. A questionnaire consisting of Leadership Style Scale developed by Crowe associates (2013) and Professional Commitment Scale for Teachers by Kaur, Ranu, and Brar (2011) was used to collect data. The findings of the study established a positive and moderate relationship between leadership style and teacher professional commitment. The results indicated that most of the teachers perceived that their principals practice delegating leadership style. Teachers were found to be committed to the teaching profession. Facilitating leadership style was observed to have a strong effect on teachers' professional commitment. The study concluded that principals' leadership style significantly affects the professional commitment of teachers in Ziarat, Balochistan.
\end{abstract}

Keywords: leadership styles, professional commitment, public schools, Ziarat.

\section{INTRODUCTION}

For bringing a positive social change in a country, education is incredibly inevitable. The quality education system is the foundation for building a strong and better nation. Advanced nations have already apprehended the significance of education. Education starts at home and then from schooling. Schools are the social, political, and economic centers of our lives, and we learn a lot throughout those years. In schools, teachers are the most essential change agents; however, this change can only be attained when teachers are responsible and committed to teaching children with the aim of making their future bright. Beside teachers, school leaders also play an essential role in fostering a positive change in students (Leithwood et al., 2004).

Leadership is a process that encourages and helps people to work more enthusiastically to achieve their objectives (Okumbe, 2013). In an organization, the execution of leadership is essential as it motivates employees and helps them achieve their organizational commitment (Garg \& Rastogi, 2006). According to Vernon-Dotson (2008), to run a school successfully, the leadership of the principal is crucial. Improving students' academic achievements with the support of competent teachers is a priority of any successful school leader (Darling-Hammond, 2014). The repeatedly mentioned idea is that the schools' performance quality is associated with its principal's leadership style and professional behavior (Fullan \& Watson, 2000). The responsibility of educational leadership commonly lies on the shoulders of a school principal and institutional administration (Allen \& Meyer, 1990). The most effective aspect of an educational institute that enhances teacher commitment is leadership (Gumus, Bulut, \& Bellibas, 2013). Nadarasa \& Thuraisingam, (2014) suggests that effective school leadership promotes learning in students, enhances teacher performance, helps collaboration among teachers, and increases teachers' job satisfaction. 
Besides the principal's leadership, another important factor for the success of a school is its teachers' commitment. Value-added work performance, lower intention of employees about leaving their job, and higher satisfaction with the organization are associated with professional commitment (Elias, 2007). Committed teachers work in the direction of school objectives and are eager to invest more time and effort in their job, and in the improvement of school (Yousef, 2000). The climate and environment of school also influence teacher's commitment. Teachers tend to be highly committed to their organization with a positive climate (Reihl \& Sipple, 1996). Similarly, it is assumed that when principals mediate, encourage teachers, recognize their efforts, provide them with positive feedback during their teaching career, and try to build healthy relations within their schools, teachers show higher commitment towards their teaching profession (Nguni, Sleegers, \& Denessen, 2006). Earlier studies have revealed a constructive association between the influence of leadership styles and organizational commitment (Saeed, Lodhi, \& Saeed, 2013).

\section{REVIEW OF LITERATURE}

Chandra and Priyono, (2016) defined leadership as "a process that enables a leader to influence a group of people for achieving the mutual goal of an organization". To Sashkin (2004), leadership is an art of the development of an organization through the transformation of the organization and its people, while Leadership style is the persistent behavior of a leader that categorizes him/her (Barbuto, 2005). Numerous studies have been conducted in the past that directed a relationship between leadership style and teacher performance, job satisfaction, motivation, school outcomes, and student achievement. The democratic, transformational, and supportive leadership lead teachers to perform more efficiently (David, Aunga, \& Masare, 2017; Duze, 2012; Wachira, Gitumu, \& Mbugua, 2017). Servant, transformational, and democratic leadership styles improve job satisfaction among employees (Cerit, 2009; Voon, Lo, Ngui, \& Ayob, 2011; Al Khajeh, 2018; Munir, \& Iqbal, 2018). Transactional, transformational, and democratic leadership styles affect the motivation of employees positively (Zareen, Razzaq, \& Mujtaba, 2015; Abdullah, Ling, \& Sufi, 2018; Nwamae \& Kayii, 2018). School outcomes were also associated with the practice of democratic and transformational leadership styles (Chin, 2007; Mohamoud, 2016) while distributed, autocratic, and democratic leadership styles influence student achievement (Dahar, Faize, Niwaz, Hussain, \& Zaman, 2010; Chang, 2011; Adeyemi, \& Bolarinwa, 2013; Ziduli, Buka, Molepo, \& Jadezweni, 2018).

Professional commitment is the extent to which a person identifies with his/her profession and accepts its values. Researchers believe that professional commitment refers to the measure of the strength of the employees' identification with the goals and values of their profession, having strong faith in it and showing considerable effort to continue in the membership of the profession (Nazari \& Emami, 2012). In several studies, teachers who were professionally committed found to be more satisfied with their jobs as well (Sustano \& Hastomo, 2012; Basu, 2016; Bashir, 2017). One of the major causes in the decreased level of organizational commitment is job stress (Alipour \& Monfared, 2015; Bhatti et al., 2016; Gilan et al., 2018). When employees are empowered, they show higher commitment to their organization (Bogler \& Somech, 2004; Nadim \& Amir, 2015; Hanaysha, 2016). It has been found that public school teachers are less committed to their profession than teachers who work in private schools (Khan, 2015; Thoker, 2017). Female teachers are comparatively more committed to their profession than their male counterparts (Basu, 2016; Shukla \& Waris, 2016; Shoaib \& Khalid, 2017).

A study conducted by Bučiūnienè and Škudienè (2008) in manufacturing companies of Lithuania on the impact of leadership styles and employees' commitment revealed a positive relationship of affective and normative commitment with transformational leadership. However, the researchers observed a negative correlation of laissez-faire leadership with employees' commitment.

Çokluk and Yllmaz (2010) found a positive association of school administrators' supportive behavior of leadership with affective and continuance commitment of teachers. The directive leading behavior of school administrators was found to be negatively linked with affective and continuance commitment.

A study conducted by Bushra, Ahmad, and Naveed (2011) on a sample of banking employees in Lahore suggests that transformational leadership style of heads positively affect employees' commitment to their organization, and on their overall job satisfaction. Omidifar (2013) in a case 
study conducted in Tehran also found a positive relationship between leadership style, organizational commitment, and job satisfaction among high school teachers.

Javaid and Mirza (2013) conducted a case study in the educational institutes of Lahore. They aimed to ascertain either transformational or transactional leadership enhances employees' organizational commitment. Study outcomes indicated that transformational leadership style was more effective in enhancing employees' commitment towards their organization.

Noraazian and Khalip (2016) examined how the transformational leadership style of principals affect the commitment of teachers in the public schools of Malaysia. The results indicated a high level of transformational leadership, and its dimension inspirational motivation having the highest level. Teacher commitment was found high, where the continuance commitment was at the highest level. The outcomes of the study also showed a positive and significant correlation of transformational headship and its dimensions with teacher commitment.

A study, on path-goal leadership and commitment of employees, was conducted by Famakin and Abisuga (2016) at manufacturing projects in Nigeria. Affective commitment and supportive leadership were positively related, however, continuance commitment was negatively associated with supportive leadership style and fairly related to achievement-oriented leadership style. Moreover, normative commitment and path goal leadership styles were not related.

Saleem, Batool, and Khattak (2017) explored that the styles of leadership and commitment of employees to an organization were significantly correlated with the role of emotional intelligence and organizational support.

Zacharo, Marios, and Dimitra (2018) surveyed 171 teachers in schools of Eastern Thessaloniki, Greece. The results revealed a significant link between teachers' organizational commitment and transformational leadership.

\section{Statement of the Problem}

Balochistan is the largest province of Pakistan by land and smallest by population (Javaid \& Jahangir, 2015). Ziarat lies in the north-east of Balochistan. In 1986, Ziarat was given the status of the District (District Development Profile, 2011). Regarding education, the literacy rate of Balochistan has been low as compared to other provinces of Pakistan; Punjab (64.7\%), Sindh (62.2\%), Khyber Pakhtunkhwa (55.3\%), and Balochistan (55.5\%) as stated by Pakistan Bureau of Statistics, 2017-18. In the year 2013, the literacy rate in district Ziarat for $15+$ male was $75 \%$ while $15+$ female was only 23\% (Ziarat District Education Plan, 2016-2017 to 2020-2021). On the list of Pakistan district ranking developed by Alif Ailaan (2017), the provincial rank of Ziarat in the education score index is 16 and the national rank is 105 based on learning score, retention score, and gender parity. On a list of school infrastructure based on accessibility to water, electricity, toilet, boundary wall, building condition is on 138.

The data in the updated list provided by Balochistan Education Management Information System (BEMIS) for the year (2018-19) shows the number of all public schools in district Ziarat including primary, middle, and high schools as 295. According to Balochistan Education Statistics (2016-2017), $73.2 \%$ of boys and $26.8 \%$ of girl schools are single-teacher primary schools. Teaching staff is 641 ( $72.5 \%$ male and $27.5 \%$ female) while the student-teacher ratio is $17.3 \%$. The studentteacher ratio shows that the teachers could have better chances of interaction with their students but despite these figures, student achievements are not progressive.

According to the data drawn from Balochistan Real-Time School Management Statistics (2019), there are many differences between the two districts of Balochistan: Ziarat and Quetta. Ziarat being a rural district of Balochistan had $79.9 \%$ student attendance, $72.9 \%$ teachers' attendance, $32.99 \%$ school facilities, $73.36 \%$ infrastructure, $26.38 \%$ teaching, and learning environment, $35 \%$ of schools visited by Education District Officer, $0.74 \%$ professional development, $1 \%$ funds utilized. The percentage of student and teacher attendance was almost the same in both the districts while the teaching-learning ratio was far less in district Ziarat than in district Quetta. Though it might be easier for the teachers to make the learning and teaching environment better in Ziarat due to a smaller number of students, unfortunately, the lack of funds, school facilities, and almost no opportunities for professional development led to problems in the education system of this area.

Ziarat is facing educational challenges including low literacy rate, drop out, untrained heads, teacher shortage, and teacher absenteeism (Ziarat District Education Plan, 2016-2017 to 2020-2021). 
Even though there are other problems like poor economic status of people, harsh weather conditions, lack of residence as well as transportation facilities for teachers that could lower their commitment, however, the focus of the present study was to assess if the leadership style of heads' play any significant role in altering teacher commitment towards teaching.

\section{Purpose of the Study}

The present research was carried out with the intention of identifying the extent of teachers' professional commitment and school leaders' management styles that they practice in public schools in District Ziarat, Balochistan. This study finds out the teachers' commitment level towards their teaching profession in the public schools. It further tried to investigate the influence of principals' leadership style on the professional commitment of teachers.

\section{Research Questions}

1. What are the perceptions of public-school teachers regarding their principals' leadership style in District Ziarat, Balochistan?

2. To what extent are the teachers in public schools committed to their profession?

3. What is the relationship between principals' leadership style and teachers' professional commitment in public schools of Ziarat?

4. Is there any effect of principals' leadership style on teachers' professional commitment?

\section{Research Objectives}

- To investigate the leadership style of school principals as perceived by teachers in public schools of Ziarat

- To find out the extent to which the teachers in public schools are committed to their profession

- To explore the relationship between principals' leadership styles and teachers' professional commitment

- To examine the effect of principals' leadership styles on teachers' professional commitment

\section{METHODOLOGY}

The study was quantitative in nature where survey instrument was used for collecting data from 33 (19 boys and 14 girls) public schools. More than 400 teachers (200 males and 200 females) from the selected schools were requested to respond to the questionnaire, out of which 243 responses were gathered (116 females and 127 males) after a period of two weeks making the response rate as $60.7 \%$.

For identifying the leadership style of principals as perceived by teachers, Leadership Style Questionnaire by Crowe associates (2013) was adopted. This questionnaire was based on four leadership styles of situational leadership that are directing, coaching, facilitating, and delegating. This questionnaire had a total of 24 statements, 6 items for each subscale. The reliability of the instrument was reported as 0.88 .

For measuring the professional commitment of public-school teachers, a scale developed by Kaur, Ranu, and Brar (2011) was used in this study. This scale measures professional commitment based on five aspects i.e., commitment to learner, commitment to society, commitment to profession, commitment to achieve excellence, and commitment to basic values. The original scale consisted of 45 statements while only 30 statements ( 6 items for each subscale) were used in the present study. The reliability of this scale was reported as 0.76 .

All the statements in both the questionnaires were scored on a 5-point Likert scale $1=$ strongly disagree, $2=$ disagree, $3=$ undecided, $4=$ agree, $5=$ strongly agree. The demographic information of the questionnaires included gender, age, teaching experience, and academic qualification. Questionnaires were translated into Urdu language for the ease of the participants.

Both the descriptive and inferential statistics were analyzed. Descriptive analyses were performed for each item and variable through frequencies, percentages, means, and standard deviation. Pearson's correlation and multiple regression were applied for analyzing the relationship and effect of principals' leadership style on instructors' professional commitment. 


\section{RESULTS AND FINDINGS}

Table 1 demonstrates the mean values of the subscales of leadership styles. The mean value of Delegating Leadership Style (M=3.66, $\mathrm{SD}=.682)$ was the highest among the four leadership styles. This value showed that the public school teachers mostly perceived that their principals use delegating leadership style in their respective schools. Majority of the participants agreed with the statement "My principal expects staff to create their own goals and objectives and submit them to him/her in the finished form" $(\mathrm{M}=3.90, \mathrm{SD}=1.00)$. The least practiced leadership style was facilitating leadership $(\mathrm{M}=3.39, \mathrm{SD}=.677)$. Around $28.7 \%$ of the participants disagreed with the statement, "My principal checks staff work on a regular basis to assess their progress and learning" $(\mathrm{M}=3.28, \mathrm{SD}=1.31)$.

Table No. 1. Mean and Standard Deviation of the Subscales of Leadership Style

\begin{tabular}{lll}
\hline Subscales of Leadership Styles & Mean & SD \\
\hline Directing leadership & 3.63 & .808 \\
Coaching leadership & 3.65 & .684 \\
Facilitating leadership & 3.39 & .677 \\
Delegating leadership & 3.66 & .682 \\
\hline
\end{tabular}

$N=243$

In Table 2, the mean scores of the subscales of professional commitment indicate that overall the public school teachers were committed. However, the teachers were highly committed to basic values $(\mathrm{M}=3.97, \mathrm{SD}=.545)$ as majority of the teachers agreed with the statement "I maintain the standards of honesty in almost all situations" $(\mathrm{M}=4.33, \mathrm{SD}=.872$. The lowest mean score was scored for commitment to the learner $(\mathrm{M}=2.85, \mathrm{SD}=.737)$, this shows that the teaching staff of public schools perceive themselves to be less committed to learners than to society, their profession, excellence, and the basic values.

Table No. 2. Mean and Standard Deviation of the Subscales of Professional Commitment

\begin{tabular}{lll}
\hline Subscales of Professional Commitment & Mean & SD \\
\hline Commitment to Learner & 2.85 & .737 \\
Commitment to Society & 3.83 & .543 \\
Commitment to Profession & 3.25 & .740 \\
Commitment to Achieve Excellence & 3.55 & .632 \\
Commitment to Basic Values & 3.97 & .545 \\
\hline
\end{tabular}
$N=243$

\section{Relationship between Leadership Style and Professional Commitment}

The Pearson Correlation ( $r$ ) was computed to explore the relationship between four subscales of leadership style and five subscales of professional commitment. The results of the Pearson Correlation Coefficient (r) are presented in Table 3.

Table 3 displays a weak correlation amid directing leadership and subscales of professional commitment while a moderate correlation existed between directing leadership and commitment to achieve excellence $(r=309, p=.000)$. Moderate correlation existed between coaching leadership style and commitment to achieve excellence $(r=.339, p=.000)$. Whereas no correlation existed amongst coaching leadership and commitment to profession $(r=.091, p=.156)$. A moderate correlation existed in facilitating leadership style and commitment to achieve excellence $(r=.333, p$ $=.000)$ and a weak correlation existed amid facilitating leadership and commitment to profession $(r=$ .183, $p=.004)$. A moderate correlation existed in delegating leadership style and commitment to achieve excellence $(r=.313, p=.000)$ and a weak correlation in delegating leadership style and commitment to basic values $(r=.222, p=.000)$.

The results incurred from analysis of the data specified the presence of a positive and moderate correlation amongst the subscales of leadership styles and professional commitment. Studies conducted by (Bučiūnienè \& Škudienė, 2008; Çokluk \& Y1lmaz, 2010; Bushra, Ahmad, \& Naveed, 2011; Omidifar, 2013; Javaid \& Mirza, 2013; Noraazian \& Khalip, 2016; Famakin \& Abisuga, 2016; 
Saleem, Batool, \& Khattak, 2017; Zacharo, Marios, \& Dimitra, 2018) also found a positive link between leadership style and organizational commitment.

Table No. 3 Pearson's Correlation among Variables $(\mathrm{N}=\mathbf{2 4 3})$

\begin{tabular}{|c|c|c|c|c|c|c|c|c|c|}
\hline & DL & $\mathrm{CL}$ & FL & DEL & CTL & CTS & CTP & CTAE & CTBV \\
\hline \multirow[t]{2}{*}{$\overline{D L}$} & 1 & $.680^{* *}$ & $.645^{* *}$ & $.705^{* *}$ & $.181^{* *}$ & $.197^{* *}$ & $.175^{* *}$ & $.309^{* *}$ & $.281^{* *}$ \\
\hline & & .000 & .000 & .000 & .005 & .002 & .006 & .000 & .000 \\
\hline \multirow[t]{2}{*}{ CL } & & 1 & $.673^{* *}$ & $.749^{* *}$ & $268^{* * *}$ & $245^{* *}$ & .091 & $.339^{* * *}$ & $.217^{* *}$ \\
\hline & & & .000 & .000 & .000 & .000 & .156 & .000 & .001 \\
\hline \multirow[t]{2}{*}{ FL } & & & 1 & $.646^{* *}$ & $.356^{* * *}$ & $260^{* *}$ & $.183^{* *}$ & $.333^{* * *}$ & $246^{* *}$ \\
\hline & & & & .000 & .000 & .000 & .004 & .000 & .000 \\
\hline \multirow[t]{2}{*}{ DEL } & & & & 1 & $.219^{* * *}$ & $.242^{* *}$ & $.226^{* *}$ & $.313^{* * *}$ & $.222^{* * *}$ \\
\hline & & & & & .001 & .000 & .000 & .000 & .000 \\
\hline \multirow[t]{2}{*}{ CTL } & & & & & 1 & $.254^{* *}$ & $.360^{* *}$ & $.462^{* * *}$ & $.175^{* *}$ \\
\hline & & & & & & .000 & .000 & .000 & .006 \\
\hline \multirow[t]{2}{*}{ CTS } & & & & & & 1 & $.225^{* *}$ & $.380^{* * *}$ & $.601^{* *}$ \\
\hline & & & & & & & .000 & .000 & .000 \\
\hline \multirow[t]{2}{*}{ CTP } & & & & & & & 1 & $.333^{* * *}$ & $291^{* *}$ \\
\hline & & & & & & & & .000 & .000 \\
\hline \multirow[t]{2}{*}{ CTAE } & & & & & & & & 1 & $.397^{* *}$ \\
\hline & & & & & & & & & .000 \\
\hline CTBV & & & & & & & & & 1 \\
\hline
\end{tabular}

**. correlation is significant at the level 0.01 (2-tailed)

$\mathrm{DL}=$ Directing Leadership, $\mathrm{CL}=$ Coaching Leadership, $\mathrm{FL}=$ Facilitating Leadership, $\mathrm{DEL}=$

Delegating Leadership, $\mathrm{CTL}=$ Commitment to Learner, $\mathrm{CTS}=$ Commitment to Society, $\mathrm{CTP}=$

Commitment to Profession, CTAE $=$ Commitment to Achieve Excellence, CTBV=Commitment to

Basic Values.

\section{Effect of Principals' Leadership Style on Teachers' Professional Commitment}

A Multiple Regression Analysis was conducted to determine the effect of leadership style on professional commitment. Four subscales of leadership style were treated as independent variables and their effect on professional commitment, a dependent variable, is displayed in Table 4, Table 5, and Table 6.

\section{Model Summary}

Table 4 (model summary) exhibits $17.7 \%$ of the discrepancy $(\mathrm{R}$ Square $=0.177$ ) in the dependent variable PC can be predicted by the independent variables (DL, CL, FL, DEL). These variables have a major consequence on professional commitment.

Table No. 4 Model Summary

\begin{tabular}{lcccc}
\hline Model & R & R Square & Adjusted R Square & Std. Error of the Estimate \\
\hline 1 & $.420^{\mathrm{a}}$ & .177 & .163 & .40396 \\
\hline
\end{tabular}

ANOVA $^{\mathrm{a}}$

Table 5 demonstrates all the statistics of ANOVA as part of multiple regression investigation. Outcomes of analysis directed the presence of a significant linear relationship $(F=12.779, p=.000)$ concerning professional commitment and leadership styles.

Table No. 5 ANOVA ${ }^{\mathrm{a}}$

\begin{tabular}{ccccccc}
\hline Model & & Sum of squares & Df & Mean square & F & Sig \\
\hline \multirow{3}{*}{1} & Regression & 8.241 & 4 & 2.085 & 12.779 & $.000^{\mathrm{b}}$ \\
& Residual & 38.837 & 238 & .163 & & \\
& Total & 47.178 & 242 & & & \\
\hline
\end{tabular}




\section{Coefficients $^{\mathrm{a}}$}

Table 6 displays the coefficients of independent and dependent variables. The model shows that $4 \%$ of variance in professional commitment is caused by directing leadership (beta $=.044, t=.486, p=$ .628). Nearly $2 \%$ variance in professional commitment is caused by coaching leadership style (beta $=$ $.018, t=.186, p=.853)$, and $13 \%$ variance in professional commitment is caused by delegating leadership style (beta $=.130, t=1.316, p=.189)$. While $27.6 \%$ of the variance in professional commitment is caused by facilitating leadership (beta $=.276, t=3.208, p=.002$ ).

Table No. 6 Coefficients ${ }^{\mathrm{a}}$

\begin{tabular}{ccccccc}
\hline Model & \multicolumn{2}{c}{ Unstandardized Coefficient } & Standardized Coefficient & & \\
& & $\mathrm{B}$ & Std. Error & Beta & $\mathrm{t}$ & Sig \\
\hline \multirow{6}{*}{1} & PC & 2.449 & .155 & & 15.793 & $.000^{*}$ \\
& DL & .024 & .050 & .044 & .486 & .628 \\
& CL & .012 & .063 & .018 & .186 & .853 \\
& FL & .180 & .056 & .276 & 3.208 & $.002^{*}$ \\
& DEL & .084 & .064 & .130 & 1.316 & .189 \\
\hline
\end{tabular}

$* . p<.001$

Note. Dependent variable: Professional Commitment (PC)

Predictors: $\mathrm{DL}=$ Directing Leadership, $\mathrm{CL}=$ Coaching Leadership, $\mathrm{FL}=$ Facilitating Leadership, DEL $=$ Delegating Leadership

\section{CONCLUSION}

The findings specified that the public school principals in district Ziarat practice delegating leadership, as the mean value of delegating leadership style was the highest among the four styles of leadership. As a delegating leader, the principal gives autonomy to their teaching staff to define their own goals and objectives and allow them to decide how to accomplish those goals. From the results of professional commitment, it was drawn that overall, the public school teachers perceive themselves as professionally committed. The results also indicate that the teachers are highly committed to the basic values whereas they are least committed to students/learners. The results also showed a significant effect of an independent variable (i.e., leadership style) on the dependent variable (professional commitment). The results suggested that the facilitating leadership style was a strong predictor of professional commitment. This finding lends provision to the assertion that facilitating leadership style boosts the professional commitment among educators when provided with time and resources to chase goals for development.

Delegating leadership style is usually low on supportive behavior whereas, facilitating leadership style focuses more on supporting and bolstering employees. That is why facilitating leadership style of principals enhances teacher professional commitment in public schools. The principals should opt to practice facilitating leadership style that could highly support educators towards achieving excellence and bridging the gap between the latest trends and current instructional practices.

In light of the findings, it has been considered that teachers were willing to achieve excellence in their profession. For this purpose, the principals should provide opportunities to teachers for professional development. The district level and provincial level authorities must arrange developmental training for teachers. The principals must also be trained so that they can easily evaluate and handle the shortcomings of the instructors.

This study was performed with the purpose of examining the perceptions of teachers only. However, it is recommended that further studies could include principals' perceptions as well regarding the level of instructors' professional commitment and leadership styles practiced in schools.

This study has been carried out in the public institutions of a rural district of Balochistan. The same study must be conducted in urban public and private schools to compare the results with the current study. It is recommended to conduct similar studies with different variables like teacher absenteeism, instructor training, development, and evaluation, principal's conflict management skills, and principal's community engagement. These studies might address the educational problems ongoing in the area. 


\section{REFERENCES}

Abdullah, A. G. K., Ling, Y. L., \& Sufi, S. B. (2018). Principal Transformational Leadership and Teachers' Motivation. Asian Education Studies, 3(1), 36-42.

Adeyemi, T. O., \& Bolarinwa, R. (2013). Principals' leadership styles and student academic performance in secondary schools in Ekiti State, Nigeria. International Journal of Academic Research in Progressive Education and Development, 2(1), 187-198.

$\mathrm{Al}$ Khajeh, E. H. (2018). Impact of leadership styles on job satisfaction. Journal of Human Resources Management Research, 2018(2018), 1-8.

Alif Ailaan (2017). Pakistan District Education Rankings 2017. Islamabad: Alif Ailaan.

Alipour, F., \& Monfared, K. M. (2015). Examining the relationship between job stress and organizational commitment among nurses of Hospitals. Journal of Patient Safety \& Quality Improvement, 3(4), 277-280.

Allen, N. J., \& Meyer, J. P. (1990). The measurement of antecedents of affective, continuance and normative commitment to the organization. Journal of Occupational Psychology, 63(1), 1-18.

Altun, M. (2017). The effects of teacher commitment on student achievement. International Journal of Social Sciences \& Educational Studies 3(3), 51-54.

Balochistan Real Time School Management Statistics. (2019). Balochistan Education Management Information System, Directorate of Education (schools), Balochistan.

Barbuto, J. E. (2005). Motivation and transactional, charismatic, and transformational Leadership: A test of antecedents. Journal of Leadership and Organizational Studies, 11(4), 26-40.

Bashir, L. (2017). Job satisfaction of teachers in Rrelation to professional commitment. The International Journal of Indian Psychology, 4(4), 1-8.

Basu, S. (2016). Professional commitment and job satisfaction among secondary school teachers. Educational Quest, 7(3), 255-259.

Bhatti, M. H., Bhatti, M. H., Akram, M. U., Hashim, M., \& Akram, Z. (2016). Relationship between job stress and organizational commitment: An empirical study of the banking sector. E3 Journal of Business Management and Economics, 7(1), 029-037.

Bogler, R., \& Somech, A. (2004). Influence of teacher empowerment on teachers' organizational commitment, professional commitment and organizational citizenship behavior in schools. Teaching and Teacher Education, 20(3), 277-289.

Bučiūnienè, I., \& Škudienè, V. (2008). Impact of leadership styles on employees' organizational commitment in Lithuanian manufacturing companies. South East European Journal of Economics and Business, 3(2), 57-66.

Bushra, F., Ahmad, U., \& Naveed, A. (2011). Effect of transformational leadership on employees' job satisfaction and organizational commitment in the banking sector of Lahore (Pakistan). International Journal of Business and Social Science, 2(18), 261-267.

Cerit, Y. (2009). The effects of servant leadership behaviours of school principals on teachers' job satisfaction. Educational Management Administration \& Leadership, 37(5), 600-623.

Chandra, T., \& Priyono, P. (2016). The influence of leadership styles, work environment and job satisfaction of employee performance studies in the school of SMPN 10 Surabaya. International Education Studies, 9 (1), 131-140.

Chang, I. H. (2011). A study of the relationships between distributed leadership, teacher academic optimism and student achievement in Taiwanese elementary schools. School Leadership \& Management, 31(5), 491-515.

Chin, J. P. (2007). Meta-analysis of transformational school leadership effects on school outcomes in Taiwan and the USA. Asia Pacific Education, 8(2), 166-177.

Çokluk, Ö. \& Yılmaz, K. (2010). The relationship between leadership behavior and organizational commitment in Turkish primary schools. Bilig, 54, 75-92.

Crowe associates (2013). Leadership styles questionnaire. https://ofd.ncsu.edu/wordpress/wpcontent/uploads/2013/01/Leadership Style Questionnaire Reading.pdf

Dahar, M. A., Faize, F. A., Niwaz, A., Hussain, M. A., \& Zaman, A. (2010). Relationship between the leadership styles and academic achievement at the secondary stage in Punjab (Pakistan). International Journal of Academic Research, 2(6), 459-462.

Darling-Hammond. (2014). One piece of the whole. American Educator, 38(1), 4-14. 
David A, Aunga, O. \& Masare, O. (2017). Effect of leadership styles on teacher's performance in primary schools of Arusha District Tanzania. International Journal of Educational Policy Research and Review, 4(4), 42-52.

District Development Profile. (2011). Planning \& Development Department, Government of Balochistan in Collaboration with UNICEF.

DuFour, R. \& Mattos M. (2013). How do principals really improve schools? Educational Leadership 70(7) 34-40.

Duze, C. O. (2012). Leadership styles of principals and job performance of staff in secondary schools in Delta State of Nigeria. An International Journal of Arts and Humanities, 1(2), 224-245.

Elias, R. Z. (2007). The relationship between auditing students' anticipatory socialization and their professional commitment. Academy of Educational Leadership Journal, 11(1), 81-90.

Famakin, I. O., \& Abisuga, A. O. (2016). Effect of path-goal leadership styles on the commitment of employees on construction projects. International Journal of Construction Management, 16(1), 67-76.

Fullan, M. \& Watson, N. (2000), School-based management: re-conceptualizing to improve learning outcome. School Effectiveness and School Improvement, 11(4), 453-473.

Garg, P., \& Rastogi, R. (2006). New model of job design: motivating employees' performance. Journal of Management Development, 25(6), 572-587.

Gilan, N. R., Ghasemi, S. R., Amini, S., Reshadat, S., Zakiei, A., \& Jamshidinazar, F. (2018). Job stress in accordance with organizational commitment and social capital. Iranian Journal of Psychiatry and Behavioral Sciences, 12(2); e10382.

Gumus, S., Bulut, O., \& Bellibas, M. S. (2013). The relationship between principal leadership and teacher collaboration in Turkish primary schools: A multilevel analysis. Education Research and Perspectives, 40(2013), 1-29.

Hanaysha, J. (2016). Examining the effects of employee empowerment, teamwork, and employee training on organizational commitment. Procedia-Social and Behavioral Sciences, 229(2016), 298-306.

Javaid, M. F., \& Mirza, M. U. (2013). Leadership style enhances the employee organizational commitment: A case study of educational institutions in Lahore. International Journals and Conference of Management, Statistics, and Social Sciences, 1(1), 64-77.

Javaid, U., \& Jahangir, J. (2015). Balochistan: A key factor in global politics. Research Journal of South Asian Studies, 30(2), 91-105.

Kaur, R., Ranu, S. K., \& Brar, S. K. (2011). Manual of Professional Commitment Scale for Teachers, National Psychological Corporation, Agra.

Khan, S. (2015). Organizational commitment among public and private school teachers. The International Journal of Indian Psychology, 2(3), 65-73.

Leithwood, K., Louis, K. S., Anderson, S., \& Wahlstrom, K. (2004). How Leadership Influences Student Learning: A Review of Research for the Learning from Leadership Project. New York: The Wallace Foundation.

Mohamoud, A. O. (2016). Effect of leadership style on school performance of the secondary schools in Wadajir District, Mogadishu, Somalia. Journal of Applied Management Science, 2(5), 5170.

Munir, H., \& Iqbal, M. Z. (2018). A study of relationship between leadership styles of principals and job satisfaction of teachers in colleges for women. Bulletin of Education and Research, 40(2), 65-78.

Nadarasa, T., \& Thuraisingam, R. (2014). The influence of principals' leadership styles on school teachers' job satisfaction - Study of secondary schools in Jaffna District. International Journal of Scientific and Research Publications, 4(1), 1-7.

Nadim, M., \& Amir, B. (2015). Role of employee empowerment in boosting organizational commitment in public sector organizations of Pakistan. Actual Problems of Economics 166(4), 294-304.

Nazari, K. \& Emami, M. (2012). Analysis of relation between organizational commitment and professional commitment. Elixir Human Res. Mgmt, 51(2012), 10661-10664.

Nguni, S., Sleegers, P., \& Denessen, E. (2006). Transformational and transactional leadership effects on teachers' job satisfaction, organizational commitment, and organizational citizenship 
behavior in primary schools: The Tanzanian case. School Effectiveness and School Improvement, 17(2), 145-177.

Noraazian, B. O., \& Khalip, M. (2016). The impact of transformational leadership and teacher commitment in Malaysian public schools. International Journal of Academic Research in Business and Social Sciences, 6(11), 388-397.

Nwamae, L., \& Kayii, N. E. (2018). Principals' leadership styles and motivation of teachers in government secondary schools in Port Harcourt Local Government Area. International Journal of Innovative Education Research, 6(3), 47-57.

Okumbe, J. A. (2013). Educational Management Theory and Practice. Nairobi: Nairobi University Press.

Omidifar, R. (2013). Leadership style, organizational commitment and job satisfaction: A case study on high school principals in Tehran, Iran. American Journal of Humanities and Social Sciences, 1(4), 263-267.

Pakistan Bureau of Statistics. (2017-2018). National Education Management Information System (NEMIS), Academy of Educational Planning and Management (AEPAM) with technical and financial support from United Nations Children's Fund (UNICEF), Pakistan.

Riehl, C., \& Sipple, J. W. (1996). Making the most of time and talent: Secondary school organizational climates, teaching task environments, and teacher commitment. American Educational Research Journal, 33(4), 873-901.

Saeed, R., Lodhi, R. N., \& Saeed, M. S. (2013). Effect of job satisfaction and leadership style on employee's organizational commitment in banking sector: A case study of Okara district, Pakistan. World Applied Sciences Journal, 26(7), 957-963.

Saleem, Z., Batool, S., \& Khattak, S. R. (2017). Relationship between leadership styles and organizational commitment: Moderating role of emotional intelligence and organizational support. Journal of Managerial Sciences, 11(1), 71-84.

Sashkin, M. (2004). Transformational leadership approaches. In J. Antonakis, A. Ciancolo, \& R. Sternberg (Eds.), The Nature of Leadership (pp. 171-196). Thousand Oaks, CA: Sage.

Shoaib, H., \& Khalid, I. (2017). Commitment with the teaching profession: Demographical view of teacher educators. Pakistan Journal of Education, 34(2), 19-36.

Shukla, A. K., \& Waris, A. (2016). Professional commitment of secondary school teachers in relation to their gender and area: A Comparative study. Global Journal for Research Analysis, 5(7), 264-265.

Susanto, Y. K., \& Hastomo, A. (2012). Organizational and professional commitment and their effect on job satisfaction. Journal of Economics, Business \& Accountancy Ventura, 15(1), 127-132.

Thoker, A. A. (2017). Professional commitment of government and private school teachers with special reference to their rural urban dichotomy. International Journal of Humanities Social Sciences and Education, 4(6): 95-103.

Vernon-Dotson, L. (2008). Promoting inclusive education through teacher leadership teams: A school reform initiative. Journal of School Leadership, 18(3), 344-373.

Voon, M. L., Lo, M. C., Ngui, K. S., \& Ayob, N. B. (2011). The influence of leadership styles on employees' job satisfaction in public sector organizations in Malaysia. International Journal of Business, Management and Social Sciences, 2(1), 24-32.

Wachira, F. M., Gitumu, M., \& Mbugua, Z. (2017). Effect of principals' leadership styles on teachers' job performance in public secondary schools in Kieni west sub-county. International Journal of Humanities and Social Science Invention, 6(8), 72-86.

Yousef, D. A. (2000). Organizational commitment: A mediator of the relationships of leadership behaviour with job satisfaction and performance in a non-western country. Journal of Managerial Psychology, 15 (1), 6-18.

Zacharo, K., Marios, K., \& Dimitra, P. (2018). Connection of teachers' organizational commitment and transformational leadership. A case study from Greece. International Journal of Learning, Teaching and Educational Research, 17(8), 89-106.

Zareen, M., Razzaq, K., \& Mujtaba, B. G. (2015). Impact of transactional, transformational and laissez-faire leadership styles on motivation: A quantitative study of banking employees in Pakistan. Public Organization Review, 15(4), 531-549. 
Ziduli, M., Buka, A. M., Molepo, M., \& Jadezweni, M. M. (2018). Leadership styles of secondary school principals: South African sases. International Journal of Educational Sciences, 22 (13), 1-10. 